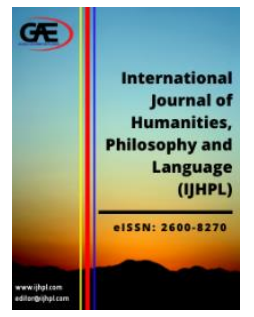

International Journal of Humanities, Philosophy and Language (IJHPL)

\title{
PROCEDURES OF FOREIGNIZING CULTURE- SPECIFIC- TERMS IN THE NOBLE QUR'AN
}

\author{
Ghada Rajeh Ayyad $^{1}$, Tengku Sepora Tengku Mahadi ${ }^{2}$
}

1 School of Languages, Literacies, and Translation, Universiti Sains Malaysia, 11800 Universiti Sains Malaysia, Penang, Malaysia.

Email: adham.translate@gmail.com

2 School of Languages, Literacies, and Translation, Universiti Sains Malaysia, 11800 Universiti Sains Malaysia, Penang, Malaysia.

Email: tsepora@usm.my

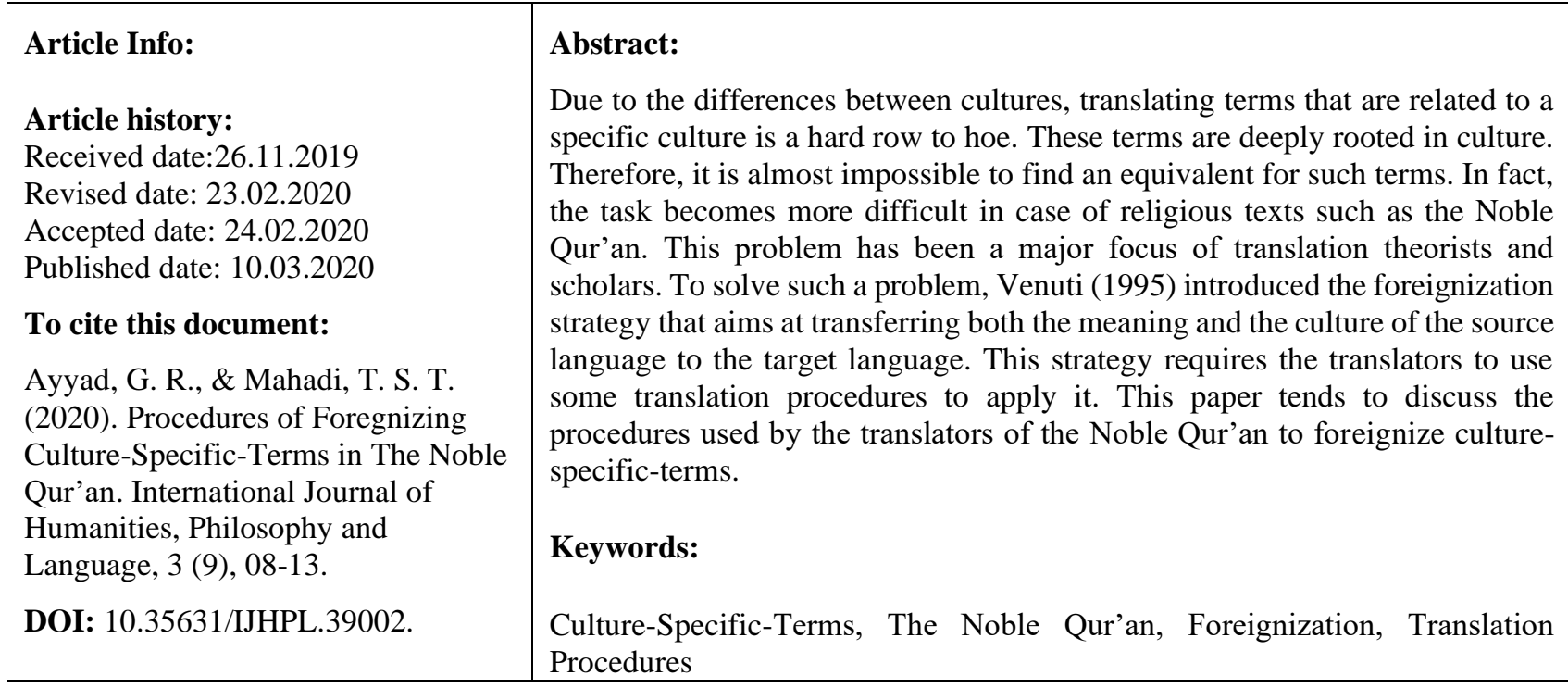

\section{Introduction}

Nowadays, translation is seen as an important discipline that plays a major role in the communication process between people all around the world. It constitutes a bridge between different nations cultures. The fast development of this field resulted in the emergence of various issues that translators may face during the translation process. Due to the differences between the source and target languages, the translators' task of achieving equivalence becomes complicated and difficult. The dissimilarity in culture between two languages such as Arabic and English causes a serious problem for translators. Translators need to choose between being source language-oriented or target language- oriented when translating terms 
related to culture. Some translators prefer to be source language- oriented and apply the foreignization strategy. Venuti (1995) introduced this strategy in an attempt to solve the problem of translating culture- specific- terms and achieve equivalence in translation. It aims at transferring the SL culture to the TL culture as much as possible. According to Venuti (1995, p.20), foreignization is "an ethnodeviant pressure on those (cultural) values to register the linguistic and cultural difference of the foreign text, sending the reader abroad".

The use of foreignization strategy can be noticed in the translation of texts that include many culture- specific- terms such as religious texts. The Noble Qur'an, the religious book for Muslims, is full of these terms. Some translators of this Holy book have employed the foreignization strategy to render these terms from Arabic into English. To do so, they used different procedures in this process. This paper aims to discuss some of the procedures used by the translators of the Noble Qur'an to foreignize culture- specific- terms.

\section{The Importance of Culture in Translation}

Culture is "a complex of beliefs, attitudes, values, and rules which a group of people share" (Larson 1984: 431). It affects language and reflects the attitudes, beliefs, customs, etc. of people. It can be said that language depends on culture and is an integral part of it. According to Wang (2014, p.2424) "it is only in language that culture can be well presented and handed down from generation to generation". Culture plays a significant role in the translation process. Nowadays "translation is rarely envisaged without one taking into account the source culture and the target culture" (Al-Hassan, 2013, p.97). Translation plays a major role in cultural exchange, "it is not only a transfer between languages but also a communication between cultures" (Li, 2010, p. 695). According to Shuttleworth \& Cowie (1997, p.35), cultural translation is "a term used informally to refer to types of translation which function as a tool for cross-cultural or anthropological research, or indeed to any translation which is sensitive to cultural as well as linguistic factors". In addition to be a linguistic broker, the translator nowadays is considered as a cultural mediator (Hatim and Mason,1990, p. 223). A cultural mediator is both bilingual and bicultural. He/she has good knowledge of both SL and TL cultures. Therefore, he/she is able to render cultural intentions and expectations to produce a text that has the same tone of the original one (Katan, 2004, p.21).

The differences between the source and target cultures can cause complications and difficulties for translators which are more severe than the ones caused by the differences in the structures of both languages. Culture creates a gap between languages. The mission of the translator is to reduce this gap as much as possible. The accuracy of a translated text depends on the translator's knowledge of the SL culture. This means that the translation is not limited to the linguistic ability of the translator, it includes his/her cultural background of the TL.

\section{Culture- Specific- Terms}

Culture-specific terms refer to "those which have no equivalents or different positions in target reader's cultural system, thus causing difficulties of translation of their functions and meanings in the source text into target text" (Moradi \& Sadighi, 2014, p. 1736). Florin (1993, p.123) defined culture-specific-terms as words that represent concepts and things that reflect a nation's culture, historical development and way of life. Gambier (2007, p.159) believes that such terms refer to various daily life aspects like sports, food, measurement units, education, names of places, art, political and legal life, which are different from one country to another. Some of these terms can be found in the TL due to globalization. Others have equivalents in the TL which makes the translation easy. One of the major concerns of translators is those terms that are deeply rooted in the SL culture. Such terms are difficult to be translated and sometimes it 
is almost impossible to find an equivalent for them in the TL. Some translators tend to delete these terms if they were not able to find any equivalents in the TL. Others try to use translation strategies and procedures to render these terms as accurate as possible and to produce a natural translation away from awkwardness. Many attempts to solve the problem of translating culturespecific-terms have been made. One of these attempts is Venuti's domestication and foreignization strategies. He introduced these strategies in 1995 in an attempt to help translators in overcoming the obstacle of translating culture-specific-terms. Moreover, Davies (2003) suggested seven procedures to be used in translating these terms. These procedures are preservation, addition, omission, globalization, localization, transformation, and creation

As Newmark stated, it is easy to detect culture-specific-terms as they are related to a specific language and cannot be translated literally. Some terms seem to be described in normal language. However, if they translated literally, the meaning will be distorted and the target text "may include an appropriate descriptive-functional equivalent" (Newmark 1988: 95). He categorized culture- specific- terms into five categories: a) ecology, b) material culture, c) social culture, d) organization, customs, ideas and e) gestures and habits.

\section{Venuti's (1995) Foreignization Strategy}

According to Hatim (2001, p.229), foreignization is "a translation which deliberately breaks target conventions by retaining something of the strangeness of the foreign text". This strategy was first suggested by Venuti in 1995 to translate culture-specific-terms. This strategy aims at retaining the source text strangeness and transferring the SL culture to the TL. Foreignizing cultural terms leads to the fact that "readers are becoming more familiar with foreign culture and accept foreignization as a norm" (De Pedro 2000, p.322). According to Munday (2001, p.189), "foreignization reflects the SL norms and reminds the target culture readers that they are dealing with a translation, thus in some ways bringing them closer to the experience of the foreign text". Using this strategy supports cultural exchange and increases the TL readers' knowledge of the SL culture. In addition, it enriches the TL with new words and expressions. Venuti prefers this strategy over the domestication one. He states that foreignization aims at developing a theory and practice of translation that resist the TL dominance and give prominence to the differences of culture and language between the source and target text (Venuti,1995). In case of foreignized text, the presence of the translator is visible as the source text foreign identity is emphasized. Venuti (1995, p.20) supports the foreignizing translation and argues that such translation is "a form of resistance against ethnocentrism and racism, cultural narcissism and imperialism, in the interests of democratic geopolitical relations". He also adds that it "seeks to restrain the ethnocentric violence of translation" (1995, p.20).

\section{Procedures of Foreignizing Culture-Specific-Terms in the Noble Qur'an}

There are many procedures used by translators of the Noble Qur'an to foreignize culturespecific-terms. These procedures are footnotes, literal translation, addition, transliteration and definition.

\section{Footnotes}

Toledano Buendía (2013, p.150) defines footnotes as "statements of variable length which are always connected to more or less definite segments of the text and they are usually found printed at the bottom of the page". In most cases, footnotes are used with words that carry cultural meaning. According to Nida (1964, pp. 238), translators use footnotes to "correct linguistic and cultural discrepancies". In addition, using footnotes can help the target text readers to better understand the source culture. (Lou \& Zhang, 2018, p. 608). Abdul-Raof (2001, p.140) believes that footnotes can play a role in penetrating "the fog of language and 
culture-specific religious words and concepts". Toledano Buendía (2013, p. 157) describes the information provided by footnotes as "verifiable and objective". In the translation of the Noble Qur'an, the translators used this procedure in foreignizing culture-specific-terms as shown in the following example:

- Wa atimmul Haija wal Umarata lillaah”

Translation: Pilgrimage + footnote "the Mecca pilgrimage (hajj) takes place once a year, in the month of Dhu'l-Hijjah..." (Asad, 1980, p.79).

In this example, the translator added a footnote explaining the pilgrimage in Islam as it is different from other religions such as Christianity. He explained the Islamic pilgrimage's rituals, time, place, clothes, etc. He conveyed the meaning equivalently by using this procedure to foreignize this term.

\section{Literal Translation}

Literal translation is a translation in which "the source language grammatical constructions are converted to their nearest translation language equivalents, but the lexical words are again translated singly, out of context" (Ordudari, 2007). Despite the fact that literal translation has been criticized by many scholars and researchers, many translators resort to use it when they fail to find an equivalence in the target text. In case of literal translation, all the ST elements are transferred to the TT with no regard to any possible change meaning in the TT. (Lomaka, 2017,238). In the following example, the translator used literal translation to foreignize CSTs:

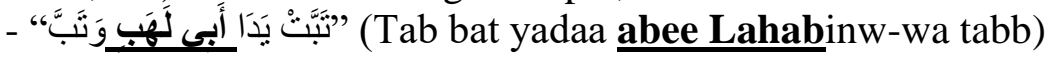

Translation: "Perish the hands of the Father of Flame! Perish he!" (Ali, 1983).

The translator chose the literal translation to translate the nickname of a person mentioned in the Qur'an. He did not convey the meaning in full.

\section{Addition}

Addition is used to provide more information about words that are related to a specific culture. In general, such additions can be found in the target text within brackets. This procedure can be found in the translation of the Noble Qur'an. For example:

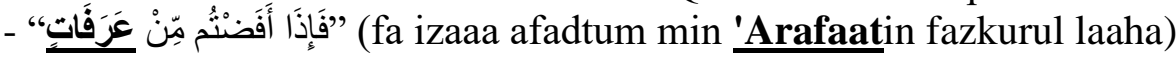

Translation: "Then when ye pour down from (Mount) Arafat" (Ali, 1983).

In addition to transliterate the word "Arafat", the translator added the word "Mount" to explain to the readers that the name "Arafat" refers to a mountain. Using the addition procedure in this case helped in clarifying the meaning. Therefore, the meaning was conveyed.

\section{Transliteration}

Transliteration is a process in which "SL graphological units are replaced by TL graphological units" (Catford, 1965, p.66). It is a transcription of the SL characters in the target language. It is used in case of CSTs such as proper nouns. The use of this procedure can be noticed in the translation of CSTs in the Noble Qur'an. For example:

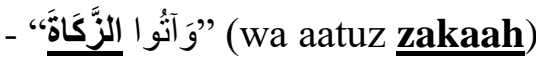

Translation: "and give Zakat" (Hilali \& Khan, 1996). 
In this example, the translator used the transliteration procedure to translate the word. However, using this procedure alone is not enough as it did not convey the meaning.

\section{Definition}

This procedure is used to define a new word to the target language. It is a useful procedure to translate cultural words. It can help in conveying their meaning equivalently. For example,

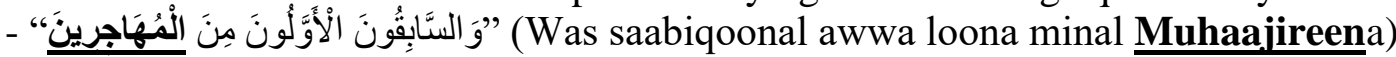

Translation: "the first of those who forsook (their homes)" (Ali, 1983).

The translator chose to define the word 'Muhaajireen' to make the meaning clear for the target text readers. In this case, the meaning is conveyed.

\section{Conclusion}

Translating culture-specific-terms is a very difficult task especially if these terms are found in religious texts. In addition to be difficult, it can be sometimes impossible as such terms are described as untranslatable by some translation scholars. However, there are strategies that can be used to overcome this problem and to help in conveying the meaning as much as possible such as Venuti's foreignization strategy. Applying this strategy requires the translators to use specific procedures. Some of these procedures are: footnotes, literal translation, addition, transliteration and definition. As noticed from the above examples, in some cases, the translator needs to use one procedure to convey the meaning. In other case, the translator is forced to use more than one procedure to transfer the meaning. in general, this strategy is very useful in translating CSTs as it conveys the meaning and the culture of the source text.

\section{References}

Abdul-Raof, H. (2001). Qur'an Translation: Discourse, Texture and Exegesis. London: Routledge.

Al-Hassan, A. (2013). The Importance of Culture in Translation: Should Culture be Translated? International Journal of Applied Linguistics \& English Literature, 2 (2), 96 -100.

Ali, A. Y. (1983). The Holy Qur'an: Text, Translation, and Commentary. Maryland: Amana Corp.

Asad, M. (1980). The Message of the Qur'an. Gibraltar: Dar Al-Andalus.

Catford, J. C. (1965) A Linguistic Theory of Translation, London: OUP.

De Pedro, R. (2000). "Cultural Misrepresentation". In Encyclopedia of Literary Translation into English. Ed. O. Clasee. Chicago: Fitzroy Dearborn Publishers, 321-322.

Florin, S. (1993). Realia in Translation. In P. Zlateva (ed.) Translation as Social Action: Russian and Bulgarian Perspectives, (pp.122-128). London: Routledge.

Gambier, Y. (2007). Doubts and Directions in Translation Studies. The Netherlands: John Benjamins.

Hatim, B. \& Mason, I. (1990). Discourse and the Translator. Longman: Longman Group Limited.

Hilali, M. \& Khan, M. (1996). Translation of the Meanings of the Noble Qur'an in the English Language. KSA: King Fahd Complex for the Printing of the Holy Qur'an.

Katan, D. (2004). Translating Cultures. Manchester: St. Jerome Publishing.

Larson, M. (1984) Meaning-Based Translation: A Guide to Cross-Language Equivalence. Lanham and New York: University Press of America, Inc.

Li, F. \& Xia, T. (2010). Translation of Words with Cultural Image. Journal of language Teaching and Research, 1 (5), 694-700.

Lomaka, A. (2017). Literal Approach to Translation: A Classification and Literature Review. XLinguae, 10 (4), 234-244. 
Luo, T. \& Zhang, M. (2018). Reconstructing Cultural Identity Via Paratexts: A Case Study on Lionel Giles' Translation of The Art of War. Perspectives, 26(4), 593- 611.

Moradi, M. (2014). Translation of Culture-Specific Phrases in the Holy Quran. Theory and Practice in Language Studies, 4(8), 1735-1746.

Munday, J. (2008). Introducing Translation Strategies. Oxon: Routledge.

Newmark, P. (1998) More Paragraphs on Translation. New Jersey University Press: Multilingual Maters.

Nida, E.A. (1964). Toward a science of translating with special reference to principles and procedures involved in Bible translating. Leiden: E.J. Brill.

Ordudari, M. (2007). Translation Procedures, Strategies and Methods. Translation Journal, 11(3).

Shuttleworth, M. and Cowie, M. (1997). Dictionary of Translation Studies. Manchester: St. Jerome.

Toledano Buendía, C. (2013). Listening to the Voice of the Translator: A Description of Translator's Notes as Paratextual Elements. Translation \& Interpreting, 5(2), 149- 162.

Venuti, L. (1995). The Translator's Invisibility: A History of Translation. London: Routledge.

Wang, L. (2014). An Approach to Domestication and Foreignization from the Angle of Cultural Factors Translation. Theory and Practice in Language Studies, 4 (11), 24232427. 